\title{
Effects of COVID-19 Lockdown on Small Scale Business Owners in Akoko South West Local Government Area of Ondo State, Nigeria
}

Olusanya Faboyede, $\mathrm{PhD}^{* 1}$

${ }^{\mathrm{T}}$ Department of History and International Studies, Faculty of Arts, Adekunle Ajasin University, Akungba-Akoko, Ondo State, Nigeria

Article History
Received: 18.11 .2021
Accepted: 24.12 .2021
Published: 15.01 .2022
Journal homepage:
https://www.easpublisher.com
Quick Response Code

\begin{abstract}
Nigeria has played significant role in the economy for sustainability growth and development in Africa. However, the outbreak and spread of the Covid-19 has affected the small and Medium Scale Enterprises (SMEs), the basic unit of economic expansion. As the pandemic continues to ravage the country, SMEs are struggling to survive due to decline in the volumes of production and harsh market condition increase with its severe effects on the population. This study intends to investigate the sound effects of the COVID-19 lockdown on small business owners in Akoko South West Local Government Area of Ondo State, Nigeria. The research method employed is a descriptive research design of the survey type. The choice of this method is based on the fact that it focuses on people, event or phenomenon. The population for this study consisted of small business owners and simple random sampling techniques was used to select the respondents from five (5) communities under Akoko South West Local Government Area of Ondo State, Nigeria. The study area is given academic attention due to strategic location for socio-economic advancement. The data collected were analysed using descriptive and inferential statistics. Frequency counts and percentage were used on the three research questions raised while chi-square was used on the two hypotheses. The findings of this study revealed that in hypothesis one, there are no significant effects of the Covid-19 lockdown on small business owner, because the p-value of each of the items is less than $0.05(\mathrm{p}<0.05)$ and, therefore, rejected. To inferred that there is a significant effect of the Covid-19 lockdown on small business owner, the hypotheses two revealed that there was no significant difference in the opinion of male and female business owners on the effects of the Covid-19 lockdown on small business owners $(t(148)=1.103 ; p>0.05)$. Therefore, the effects of the Covid-19 lockdown on small business owners were not rejected.

Keywords: Covid-19, lockdown, small business owners.
\end{abstract}

Copyright (C) 2022 The Author(s): This is an open-access article distributed under the terms of the Creative Commons Attribution 4.0 International License (CC BY-NC 4.0) which permits unrestricted use, distribution, and reproduction in any medium for non-commercial use provided the original author and source are credited.

\section{INTRODUCTION}

As the world is struggling to fight off Covid19 pandemic, different countries are witnessing unprecedented economic slowdowns and shutdowns. In Nigeria, for instance, the spread of Covid-19 is affecting the stability of Small and Medium Scale Enterprises (SMEs) and finances are dwindling as the pandemic continues to ravage the country. The SMEs are not growing as a result of the restriction of human movement on the supply of goods and services (Adekoya and Aibangbee, 2020) due to the consequences of the pandemic. Coronavirus disease 2019 (Covid-19) is a respiratory illness that can spread from one person to another person. The virus that caused Covid-19 was a novel Coronavirus that was first identified during an investigation into its outbreak in Wuhan, China, which claimed to be originated in bats or pangolins (https://www.thermofisher.com/respiratory/panelsarsc....). Its first transmission to humans was traced to a local seafood market ("wet market") in Wuhan, China. The earliest cases had contact history with the original seafood market (Akpoveta and Joy, 2020) and since then, the virus continued to spread like wild fire from person-to-person contact.

In the light of the outbreak of Covid-19, and its devastating effects on entrepreneurial growth, this study, therefore, seeks to discuss the impact of COVID19 on the small business landscape in Akoko South West Local Government Area of Ondo State, Nigeria as 
a result of the critical time faced by the local business owners were at critical time.

Across the full sample, $73 \%$ of businesses had temporarily closed and nearly all of these closures were due to decisive effects of COVID-19 on the small scale economy and entrepreneurial skill. Respondents that had temporarily closed largely pointed to reduction in demand and employee health concerns for closure, with disruptions in the supply chain being less of a factor. On average, the businesses reported had reduced their active employment by $39 \%$ since January, 2021. The decline was particularly sharp in Akoko South West Local Government Area of Ondo State, Nigeria, where $54 \%$ of small scale firms were closed and employment was down by $47 \%$. The widespread closing of businesses and stores in the Local Government due to the Coronavirus was unprecedented (Field work, 2021).

\section{Research questions}

The following research questions were formulated for this study:

1. What is the Socio-economic impact of Covid19 ?

2. What are the challenges faced by the Small and Medium Enterprise (SMEs) operators during the outbreak of Covid-19?

3. How can SMEs operators prepare ahead of any pandemic like Covid-19?

\section{Research Hypothesis}

H01: there is no significant effect of the Covid-19 lockdown on small business owners.

H02: there is no significant difference in the opinion of male and female business owners on the effects of the Covid -19 lockdown on small business owners.

\section{Conceptual Clarifications}

\section{Small Scale Business}

In the Nigerian context, a small scale business is any business that is owned, financed, managed and controlled by a sole proprietor or partners of about two persons with total assets of less than four million naira (12,698 USD) with less than fifty employees at the same time. $50 \%$ of Nigerian population operates different forms of small scale businesses or another as means of livelihood and survival. Obiakor \& Adeniran (2020) posits that a business enterprise shall be called small scale business undertaking; if the investment in fixed assets, plant and machinery either held on ownership basis or on lease or on hire purchase does not exceed 1,587 USD and in no way owned, controlled or a subsidiary of any other industrial undertaking.

Sanni (2020) his description refers to small scale enterprise as the employees not more than 50 (fifty) and with initial capital equipment of 1,905 USD. The business should be independent and be managed autonomously in small size, both in terms of sales and employees. The capital to operate the business is supplied by only one person or by a few people who are the managers of the business. It is usually a sole proprietorship, a partnership, or a family owned corporation. They are responsible only to themselves and are independent of a board of directors or a "corporate office".

\section{The Small Scale Business Owners and the Nigeria's Economy}

The small business plays a crucial role in the operation of a nation's economy. However, many citizens are unaware of its pervasiveness because small business scale tends to be overshadowed by new items the big business. Thus, Ozili (2020) asserts that the Nigerian economy is built on small business and it continues to thrive on the local economy framework of locally owned operations. In contrast, Lenon (2020) mentions that in developing countries, the small scale businesses usually assist bigger industries to thrive with new projects. As a result, the small scale business contributes to the growth of economy by creating employment opportunities to people around the project sites. No doubt, small business has been the main breakthrough with which rapid industrialisation aids competitive economic growth.

\section{Socio-Economic Effects of the COVID-19 Lockdown among Small Scale Business Owners \\ In this segment, the study examines the widespread of closing of stores and businesses in Akoko South West Local Government Area of Ondo State, Nigeria due to serious effects of Corona virus. Stores and small medium businesses were closed by policy mandate, downward demand shifts, health concerns, among other factors. Many of the closures were permanent because of the inability of owners to pay off some debts incurred during the harsh period of Corona virus in Nigeria.}

This study, therefore, provides the first estimates of the earliest stage effects of COVID-19 on small business owners from April 2020 CPS micro data. I find that the number of working business owners plummeted from 1.0 million in February 2020 to 1.5 million in April 2020 because of COVID-19 mandates of health and economic driven demand shifts. The loss of 0.5 million active business owners was the largest drop on record. When conditioning on working roughly 2 or days/week, the losses are even larger. Total hours worked by all business owners dropped by $40 \%$. The incorporated businesses were more stable, however, their sales output also dropped at $30 \%$ from February to April 2020. The estimates from the weekly records revealed that roughly $50 \%$ of businesses recorded large negative effect from the spread of COVID-19 pandemic and that only $15 \%-20 \%$ of businesses had enough cash on hand to cover 3 months of loss operations. 
It is never the intention of any small business operator to fail but sometimes failure usually occurred due to some unforeseen circumstances. Business failure can be seen as the closure or cessation of activity that results in a loss to its creditor and, it can also be noticed when there is no ability to redeem or repay the loan advance on the agreed installment on maturity. On this claim, Akpoveta and Joy (2020) observed that a small industry was considered a failure, if the wages cannot be as scheduled.

\section{The Effects of Covid-19 on the Small Scale Business and Economy of Akoko Southwest Local Government Area}

For lack of space, this study shall identify few consequence of Covid-19 on small scale business owners in the local areas. The unemployment rate was (and is still) the immediate effect of small scale business failure is unemployment and poverty with its grievous effects on social mobility of entrepreneurs and dependents. About $75 \%$ of Nigerians are employed by small scale business operators. Apart from employment, Nigeria statistics are clearly out of trend relative to the other countries listed in the table. However, beyond these three parameters, small businesses are also noted both theoretically and empirically, for overall total factor of productivity that is efficiency as usually defined by virtue of its pattern of technological choice. Unemployment rate in Nigeria increased to $23.90 \%$ in 2011 from $21.10 \%$ in 2010 as reported by the National Bureau of Statistics. Historically, from 2006 until 2011, Nigeria unemployment rate averaged $14.6 \%$ reading an all times high of $23.9 \%$ in December of 2011 and a record low of $5.3 \%$ in December of 2006 (https://wwww.statista.com >statistics).

In Nigeria, the unemployment rate measures the number of people actively looking for a job as a percentage of the labour force.

Similarly, the loss of jobs has caused social problems to millions of people and as such, societal peace and harmony was threatened and it has led to armed robbery, kidnapping, duping, hired killing, among many other evil works are perpetrated in Nigeria. In the same vein, the economic wastages in terms of capacity wastage, idle inventory, losses of revenue to office machineries, equipment and building usually caused set back to developmental activities.

The financial institutions face losses as principal loans with its interest cannot be recovered due to businesses failure. The non-performance loans weakened the long run ability to disburse loans to their customers. The employees get disoriented and normally loss their bargaining power wherever they go in search of jobs. It is difficult to dilute the demoralization of the employees.

\section{ReSEarCh Methodology}

The research design employed in this study is a descriptive research design of the survey type. The choice of this method is based on the fact that it focuses on people, event and phenomenon.

\section{Population}

The targeted population for this study consisted of small business owners in Akoko South West Local Government Area of Ondo State, Nigeria.

\section{Sample}

One hundred and fifty (150) small business owners in Akoko Akoko South West Local Government Area of Ondo State, Nigeria were sampled. Simple random sampling techniques was used to select the respondents from five (5) communities under Akoko South West Local Government Area of Ondo State, Nigeria. Simple random sampling techniques allow every respondent to participate in the study under investigation. The population of this study is thirty (30) small business owners in Akoko South West Local Government Area, Ondo State, Nigeria.

\section{The selected communities include}

- Thirty (30) small business owners from Akungba, Akoko South West Local Government Area, Ondo State, Nigeria.

- Thirty (30) small business owners from Oka, Akoko South West Local Government Area, Ondo State, Nigeria.

- Thirty (30) small business owners from Oba, Akoko South West Local Government Area, Ondo State, Nigeria.

- Thirty (30) small business owners from Supare, Akoko South West Local Government Area, Ondo State, Nigeria.

- Thirty (30) small business owners from Ayegunle, Akoko South West Local Government Area, Ondo State, Nigeria.

\section{Instrument}

Questionnaire was a research instrument to explain information from the respondents. The questionnaire was open ended. The study employed a-4 point Likert scale rating summation of strongly Agreed (SA), Agreed (A), Disagree (D) and Strongly Disagreed (SD) to measure responses of the respondents.

\section{Data Collection}

The instrument for this study was a-5 item standard questionnaire on each research question. The instrument was complemented with the use of Focus Group Discussion (FGD) whereby the researcher interviewed the respondents to obtain information verbally. The researcher with research assistant visited each small business owners in each community to bring out information. 


\section{Data Analysis}

The analysis of the data obtained from questionnaire was analysed using descriptive statistical methods of frequency counts, percentage and Chisquare.

\section{RESUlTS AND DISCUSSION}

Research Question 1: What is the Socio-economic impact of Covid-19?

Table-1: Percentage showing the responses of respondents on the Socio-economic impact of Covid-19

\begin{tabular}{|c|c|c|c|c|c|}
\hline $\mathbf{S} / \mathbf{N}$ & Items & SA & $\mathbf{A}$ & D & SD \\
\hline 6. & Covid-19 affected my production & $\begin{array}{l}61 \\
(40.7)\end{array}$ & $\begin{array}{l}53 \\
(35.3)\end{array}$ & $\begin{array}{l}30 \\
(20.0)\end{array}$ & $6(4.0)$ \\
\hline 7. & I ran into loses during the lockdown & $\begin{array}{l}53 \\
(35.3)\end{array}$ & $\begin{array}{l}39 \\
(26.0)\end{array}$ & $\begin{array}{l}38 \\
(25.3)\end{array}$ & $\begin{array}{l}20 \\
(13.3)\end{array}$ \\
\hline 8. & I could not sell my product during lockdown & $\begin{array}{l}25 \\
(16.7)\end{array}$ & $\begin{array}{l}70 \\
(46.7)\end{array}$ & $\begin{array}{l}16 \\
(10.7)\end{array}$ & $\begin{array}{l}39 \\
(26.0)\end{array}$ \\
\hline 9. & I made more income during Covid-19 & $\begin{array}{l}10 \\
(6.7)\end{array}$ & $\begin{array}{l}49 \\
(32.7)\end{array}$ & $\begin{array}{l}47 \\
(31.3)\end{array}$ & $\begin{array}{l}44 \\
(29.3)\end{array}$ \\
\hline 10. & I was able to secure loan which boosted my business. & $\begin{array}{l}9 \\
(6.0)\end{array}$ & $\begin{array}{l}53 \\
(35.3)\end{array}$ & $\begin{array}{l}37 \\
(24.7)\end{array}$ & $\begin{array}{l}1+ \\
(34.0)\end{array}$ \\
\hline
\end{tabular}

Source: Field Work 2021

Table 6 revealed responses of respondents on the socio-economic impact of Covid-19. On item 6, more than two-third, $76 \%$ of the respondents agreed that Covid-19 affected their production, while $24 \%$ of the respondents disagreed with the item. Therefore, one can conclude that majority of the small business owners are affected by the Covid-19 pandemic.

On item seven, $61 \%$ of the respondents are of the opinion that they ran into loses during the lockdown, while $39 \%$ of the respondents held contrary opinion. This implies that small business owners ran into loses during the lockdown.

On items eight, $63 \%$ of the respondents affirmed that they could not sell their product during lockdown, while $37 \%$ of the respondents opined that they are able to sell their product during lockdown. Hence, one could opine that small scale business owners are not able to sell their product during the lockdown.

On item nine, $39 \%$ of the respondents opined that they made more income during Covid-19 lockdown, while $61 \%$ of the respondents held contrary opinion. By implication, one could say small scale business owners do not make more income during Covid-19 lockdown.

On item $10,41 \%$ of the respondents concurred that they are able to secure loan which boosted their businesses during the lockdown, while $59 \%$ of the respondents did not agree with the item. Therefore, it was concluded that small scale business owners are unable to secure a loan during the Covid-19.

Research Question 2: What are the challenges faced by the Small and Medium Enterprise? (SMEs) operators during Covid-19?

Table-2: Percentage showing the responses of respondents on the challenges faced by the Small and Medium Enterprise (SMEs) operators during Covid-19.

\begin{tabular}{|l|l|l|l|l|l|}
\hline S/N & Items & SA & A & D & SD \\
\hline 11. & Closedown of business shops or centres & 28 & 75 & 38 & $9(6.0)$ \\
& & $(18.7)$ & $(50.0)$ & $(25.3)$ & \\
\hline 12. & Low turnout of consumer rate & 39 & 54 & 47 & 10 \\
& & $(26.0)$ & $(36.0)$ & $(31.3)$ & $(6.7)$ \\
\hline 13. & Increase the expiring rate of goods in the store & 42 & 61 & 38 & $9(6.0)$ \\
& & $(28.0)$ & $(40.7)$ & $(25.3)$ & \\
\hline 14. & Increase debt of small scale business operators & 54 & 47 & 34 & 15 \\
& & $(36.0)$ & $(31.3)$ & $(22.7)$ & $(10.0)$ \\
\hline 15. & Inadequate funding to finance my business & 53 & 56 & 33 & $8(5.3)$ \\
& & $(35.3)$ & $(37.3)$ & $(22.0)$ & \\
\hline
\end{tabular}

Source: Field Work 2021 
Table 2 showed the responses of respondents on the challenges faced by the Small and Medium Enterprise (SMEs) operators during Covid-19. On item eleven, $69 \%$ of the respondents opined that one of the challenges faced by small and medium enterprise operators is closedown of business shops and centre, while $31 \%$ of the respondents are against the item. Therefore, small and medium enterprise operators are experienced closedown of business shops and centres.

On item twelve, $62 \%$ of the respondents affirmed that small and medium enterprise operators are faced with low turnout of consumers' rate, while $38 \%$ of the respondents disagreed that there was low turnout during the lockdown. This implies that there was low turnout during the Covid-19.

On item thirteen, $69 \%$ of the respondents agreed that there is an increase in the expiring rate of their goods in the store during the Covid-19, while $31 \%$ of the respondents disagreed with the item. Thus, one could have opined that Covid-19 increased the expiring rate of goods of small and medium scale enterprise operators.

On item fourteen, $67 \%$ of the respondents opined that Covid-19 increased debt of small scale business operators, while $33 \%$ of the respondents are against the item. This implies that there was an increase in the debt of small scale business operators during the Covid-19 pandemic.

On item fifteen, $73 \%$ of the respondents confirmed that there was inadequate funding to finance their businesses during the Covid-19 lockdown, while $37 \%$ of the respondents are against the item. This means that small and medium enterprise operators were unable to get adequate funding to finance their businesses during the lockdown.

Research Question 3: How can Small and Medium Enterprises (SMEs) operators prepare ahead of any pandemic like Covid-19?

Table-3: Percentage responses of respondents on how Small and Medium Enterprises (SMEs) operators prepare ahead of any pandemic like Covid-19.

\begin{tabular}{|c|c|c|c|c|c|}
\hline $\mathbf{S} / \mathbf{N}$ & Items & SA & $\mathbf{A}$ & D & SD \\
\hline 16. & By partnering with good financial institution & $\begin{array}{l}54 \\
(36.0)\end{array}$ & $\begin{array}{l}52 \\
(34.7)\end{array}$ & $\begin{array}{l}27 \\
(18.0)\end{array}$ & $\begin{array}{l}17 \\
(11.3)\end{array}$ \\
\hline 17. & By supplying adequate information ahead of the Pandemic & $\begin{array}{l}42 \\
(28.0)\end{array}$ & $\begin{array}{l}53 \\
(35.3)\end{array}$ & $\begin{array}{l}43 \\
(28.7)\end{array}$ & $12(8.0)$ \\
\hline 18. & $\begin{array}{l}\text { By encouraging small and medium enterprises to go into } \\
\text { cooperative society }\end{array}$ & $\begin{array}{l}33 \\
(22.0)\end{array}$ & $\begin{array}{l}72 \\
(48.0)\end{array}$ & $\begin{array}{l}31 \\
(20.7)\end{array}$ & $14(9.3)$ \\
\hline 19. & $\begin{array}{l}\text { By making special loan available for small and medium scale } \\
\text { enterprise operators }\end{array}$ & $\begin{array}{l}71 \\
(47.3)\end{array}$ & $\begin{array}{l}53 \\
(35.3)\end{array}$ & $\begin{array}{l}22 \\
(14.7)\end{array}$ & $4(2.7)$ \\
\hline 20. & By giving grants to small scale business owners & $\begin{array}{l}41 \\
(27.3)\end{array}$ & $\begin{array}{l}60 \\
(40.0)\end{array}$ & $\begin{array}{l}36 \\
(24.0)\end{array}$ & $13(8.7)$ \\
\hline
\end{tabular}

Source: Field Work 2021

Table 3 revealed that responses of respondents on how Small and Medium Enterprises (SMEs) operators can prepare ahead of any pandemic like Covid-19. On item sixteen, large number $71 \%$ of the respondents are of the opinion that Small and Medium Enterprises (SMEs) operators may partner with good financial institution in other to prepare ahead of any pandemic like Covid-19, while $29 \%$ of the respondents held contrary opinion. Thus, one could opine that partnering with good financial institution may help Small and Medium Enterprises (SMEs) operators prepare ahead of any pandemic.

On item seventeen, $62 \%$ of the respondents agreed that supplying adequate information ahead of the pandemic tends to help Small and Medium Enterprises (SMEs) operators prepare ahead of any pandemic while $37 \%$ of the respondents disagreed with the item. This implies that supplying adequate information to Small and Medium Enterprises (SMEs) operators may help them prepare ahead of any pandemic.
On item eighteen, $70 \%$ of the respondents affirmed that involvement of small and medium enterprise in cooperative society is likely to help them prepare ahead of any pandemic, while $30 \%$ of the respondents disagreed with the item. Therefore, one could say that encouraging small and medium enterprise to go into cooperative society tends to help them prepare ahead of any pandemic.

On item nineteen, $83 \%$ of the respondents concurred that making special loan available for small and medium scale enterprise operators may help them prepare ahead of any pandemic, while $17 \%$ of the respondents were against the item. By implication, it can be concluded that providing special loan to small and medium scale enterprise operators may help them prepare ahead of any pandemic.

On item twenty, $67 \%$ of the respondents agreed that providing grants to small scale business owners tends to help them prepare ahead of any pandemic, while $33 \%$ of the respondents disagreed that 
providing grants to small scale business owners may help them prepare ahead of any pandemic. Therefore, it was concluded that providing grants to small scale business owners may help them prepare ahead of any pandemic.

\section{Test of Research Hypotheses}

Hypothesis 1: There is no significant effect of the Covid-19 lockdown on small business owner.

Table-4: Chi-square showing the significant effects of the Covid-19 lockdown on small business owners.

\begin{tabular}{|l|l|l|l|l|l|l|l|l|l|}
\hline S/N & Items & SA & A & D & SD & X2 & df & P & Decision \\
\hline 6. & Covid-19 affected my production & 61 & 53 & 30 & 6 & 49.09 & 3 & .000 & Sig. \\
\hline 7. & I ran into loses during the lockdown & 53 & 39 & 38 & 20 & 14.64 & 3 & .002 & Sig. \\
\hline 8. & I could not sell my product during Lockdown & 25 & 70 & 16 & 39 & 44.72 & 3 & .000 & Sig. \\
\hline 9. & I made more income during Covid-19 & 10 & 49 & 47 & 44 & 27.23 & 3 & .000 & Sig. \\
\hline 10. & I was able to secure loan which boosted my business. & 9 & 53 & 37 & 51 & 32.93 & 3 & .000 & Sig. \\
\hline & GRAND TOTAL & & & & & $\mathbf{1 6 8 . 6 1}$ & $\mathbf{1 5}$ & & \\
\hline
\end{tabular}

Source: Field Work 2021

Table 4 showed that there was a significant effect of the Covid-19 lockdown on small business owners. The cumulative chi-square calculated is 168.61 , while degree of freedom is 15 . The p-value of each of the items is less than $0.05 \quad(\mathrm{p}<0.05)$. Therefore, hypothesis one, which stated that there was no significant effect of the Covid-19 lockdown on small business owners was rejected. Hence, one could say that there is a significant effect of the Covid-19 lockdown on small business owners.

Hypothesis 2: There is no significant difference in the opinion of male and female business owners on the effects of the Covid-19 lockdown on small business owner.

Table-5: T-test showing the significant difference in the opinion of male and female business owners on the effects of the Covid-19 lockdown on small business owners.

\begin{tabular}{|c|l|l|l|l|l|l|l|}
\hline Variable & $\mathbf{N}$ & Mean & SD & DF & t-cal & P & Decision \\
\hline Male & 74 & 15.61 & 3.174 & & & & \\
\hline & & & & 148 & 1.103 & 272 & Not Sig \\
\hline Female & 76 & 15.00 & 3.563 & & & & \\
Female & 76 & 15.00 & 3.563 & & & & \\
\hline
\end{tabular}

Source: Field Work

Table 5 revealed that there was no significant difference in the opinion of male and female business owners on the effects of the Covid-19 lockdown on small business owner [ $\mathrm{t}(148)=1.103 ; \mathrm{p}>0.05]$. Thus, hypothesis two stated that there was no significant difference in the opinions of male and female business owners on the effects of the Covid-19 lockdown on small business owners and also not rejected. Therefore, one could opine that male and female business owners have equal opinion on the effects of the Covid-19 lockdown on small business owners.

\section{DiSCUSSION OF FINDINGS}

The result of research question one revealed that Covid-19 had a negative impact on Small and Medium Enterprises (SMEs) operators. During the Covid-19 pandemic, there was a decrease in the production of Small and Medium Enterprises (SMEs) operators. The Small and Medium Enterprises (SMEs) operators ran into losses as majority of them could not sell their product during the lockdown. Due to the losses, there was a decrease in their income, and also the Small and Medium Enterprises (SMEs) operators could not get a loan to boost their businesses.
By implication, it was concluded that Covid19 pandemic had a negative impact on Small and Medium Enterprises (SMEs) operators. This result collaborates the findings of Global Alliance for Improved Nutrition (GAIN, 2020), which reported that the main impacts of Covid-19 on SMEs were decreased sales, difficulty in accessing inputs, difficulty in accessing finance and difficulty in paying staff wages. Of the impacted firms lamented that it would be difficult to recover; they also reported that the impact was severe and likely to cause business closure. Furthermore, GAIN (2020) reported that majority of firms reported changing their production volume as a result of the pandemic, while some reported to stop production. Considering the firm's product's sales price, approximately most of respondents had changed their product's price as a result of the pandemic. Furthermore, this result is supported by the findings of Aderemi, Ojo, Ifeanyi \& Efunbajo (2020), which showed that the enterprises experienced reduction in production and sales during the lockdown. Also the surveyed enterprises experienced a spike in reduction of contracts and deliveries.

The result of research question two showed that closedown of business shops and centres, low 
turnout of consumer rate, increase in expiring date of goods in the store, increase in debt of small scale business operators and inadequate funding to finance small scale businesses were the challenges faced by small and medium enterprise operators during the Covid-19 pandemic. This result is in line with the study of Bassey, Nwagbara and Bisong (2014), Akpan (2013) and Michael (2007). Bassey, Nwagbara and Bisong (2014) revealed in their findings that a number of challenges faced by small and medium enterprise include poor planning, poor price fixing, poor product service, absence of an enabling environment, security concerns, multiple taxation, over- dependence on certain individuals, weak financial capacity to undertake research and development/procurement of other costly support services, lack of business connection and lack of proper record keeping. Also, the findings of Akpan (2013) classified the problems facing small scale business owners as follows; poor planning, business location, financial problems, management policies, manpower, government policies, technology/infrastructure and competition.

Furthermore, Michael (2007) identifies in his study reasons why most small businesses fail. These include lack of management systems, lack of vision, purpose or principles, lack of financial planning and review, over-dependence on specific individuals in business and poor market segmentation and/or communicate company goals, competition or lack of market knowledge, inadequate capitalization, absence of a standard-quality program and owners concentrating or the technical, rather than the strategic work at hand.

The result of research question three revealed the opinion of Small and Medium Enterprises (SMEs) operators on how government can assist them to prepare ahead in case if there is another pandemic similar to Covid-19. The operators opined that partnering with good financial institutions, supplying adequate information to them, encouraging them to go into cooperative society, easy access to loan and provision of grants to them may help them prepare ahead of any pandemic. This result is supported by the opinion given by respondents in Global Alliance for Improved Nutrition (GAIN, 2020) survey, which stated that respondents reported that the government had taken actions to support businesses. The main actions cited were financial support, information sharing, supporting workforce continuity, re-opening retail outlets, providing incentives and strengthening linkages between SMEs and national multi-stakeholder platforms on decisions affecting business. Some of the respondents opined the type of support they need from the government which include grants from government, grants from other NGOs or private sector.

The result of hypothesis one showed that there was a significant effect of the Covid-19 lockdown on small business owners. This implies that there was a decrease in the production of Small and Medium Enterprises (SMEs) operators during the Covid-19 lockdown. The Small and Medium Enterprises (SMEs) operators ran into losses as majority of them could not sell their product during the lockdown. Due to the losses, there was a decrease in their income and also, the Small and Medium Enterprises (SMEs) operators could not get a loan to boost their businesses. This result collaborate the findings of Abioye, Ogunniyi \& Olagunju (2020) and Chukwuka and Ekeruche (2020). The findings of Abioye, Ogunniyi \& Olagunju (2020) found out that the pandemic, as well as governmental mobility restrictions, that is, partial and total "lockdowns" have both had significant effects on Small and Medium Scale Enterprise in Nigeria reported by entrepreneurs. While the study of Chukwuka and Ekeruche (2020) shows that Nigeria economy that was projected to experience $2.5 \%$ GDP growth, has been truncated by the pandemic leading to a higher increase of the nation's debt servicing to revenue ratio at $60 \%$ amid the falling prices of oil. Furthermore, Seth et al. (2020) revealed that the direct effects of the pandemic come through low coping strategies, income losses, and reduced investment.

The result of hypothesis two revealed that that there was no significant difference in the opinion of male and female business owners on the effects of the Covid-19 lockdown on small business owner. Therefore, male and female business owners opined that there was a decrease in the production of Small and Medium Enterprises (SMEs) operators during the Covid-19 lockdown. The Small and Medium Enterprises (SMEs) operators ran into losses as majority of them could not sell their product during the lockdown. Due to the losses, there was a decrease in their income and also, the Small and Medium Enterprises (SMEs) operators could not get a loan to boost their businesses. This result collaborates the findings of Global Alliance for Improved Nutrition (GAIN, 2020), which reported that women owned firms were equally likely to report being impacted by the pandemic and generally were impacted in the same ways as men-owned firms, with the same severity and changes over time.

However, GAIN (2020) opined that they were less likely to report difficulty accessing financing or limited financial reserves as impacts. There were no differences in production or sales price changes. Furthermore, women-owned firms were slightly less likely to anticipate future disruptions to their supply chains, though the majority still expected such disruptions. There were no differences in the types of disruptions expected. Women-owned firms were less likely to be interested in exploring new business areas as a result of the pandemic. Furthermore, womenowned firms offered similar reports to men-owned/coowned firms on actions taken by government and on which actions they found most helpful. They were also 
similar in that they overwhelmingly felt additional support was needed, and generally agreed on the types needed aside from being less likely to suggest workforce continuity measures and keeping borders open. However, GAIN (2020) concluded that there were no gender differences in the share of firms reporting receiving support to date.

\section{RECOMMENDATIONS AND CONCLUSION}

Based on the result of the analysis of this study, the following recommendations were made; the Government should ensure that they give grants to Small and Medium Enterprises (SMEs) operators in order to boost their businesses. The Small and Medium Enterprises (SMEs) operators should belong to cooperate bodies that would assist them whenever they are faced with financial challenges, while Technical assistance can be provided to help SMEs adapt business models, reach consumers online, or adopt processing or packaging. The financial institutions and money lending organization should reduce the percentage paid for loans in order to enable Small and Medium Enterprises (SMEs) operators have easy access to loans.

In the light of the above suggestions, the study based on its findings, therefore, concluded that Covid19 lockdown had (and is still) has a negative effect on Small and Medium Enterprises (SMEs) operators in Akoko South West Local Government Area of Ondo State, Nigeria.

\section{REFERENCES}

- Abioye, O., Ogunniyi, A. Olagunju, R. (2020). Estimating the Impact of Covid-19 on Small and Medium Scale Enterprise: Evidence from Nigeria, iAfrican Economic Coference, Gloverde, 24December.

- Adekoya, A., \& Aibangbee, O. (2020). Covid-19 Economic Downturn - The Implication for Corporate Debts and Recovery Actions in Nigeria. SSRN Electron. https://doi.org/10.2139/ssrn.3583053.

- Aderemi, T.A., Ojo, L.B., Ifeanyi, O.J., \& Efunbajo, S.A. (2020). Impact of Corona Virus (Covid-19) Pandemic on Small and Medium Scale Enterprises (SMEs) in Nigeria: A Critical Case Study, (Acta Universitatus Danubius (Economica), vol. 16

- Akpan, N. (2013). Unpublished Lecture Note on Small scale Business Management, University of Uyo, Akwabon State.
- Akpoveta, A., Joy, O. (2020). COVID-19 Pandemic: Nigeria's Economic and Business Disruptions, https://doi.org/10.2705/isjassr.v2i4.45.

- Bassey, U.U., Nwagbara, E.N., \& Bisong., A. Entrepreneur Development in Nigerian Universities: A Theretical Approach. Ca, abarEntrepreneurialm Development Centre, University of Calabar.

- Chukwueka, O., \& Ekeruche, M.A. (2020). "Understanding the Impact of the Covid-19 outbreak on the Nigerian Economy", African in Focus/ www.brooki \& and for more details, see Ekeruche, M.A., 2020. The impact of COVID-19 on Nigeria's economy (www Document). URL /article/the-impactof-covid-19-on-nigeriaseconomy (accessed 6.30.20).

- GAIN. (2020). Impacts of Covid-19 on Small Meium-Sized Enterprises in the Food System: Results of an online survey. Geneva: Global Alliance for Improved Nutrition (Gain).

- Lenon, O. (2020). What is the economic impact of COVID-19 in Nigeria? (www Document).CDC Group. URL https://www.cdcgroup.com/en/newsinsight/insight/articles/what-is- the-economicimpact-of-covid-19-in-nigeria/ (accessed 6.30.20). https://www.statista.com>statistics

- Michael, G. (2007). Why most Small Business Fail and What you can do about it. Retrieved on 28-112021, from http://www.tradingeconomics.com

- Obiakor, T., Adeniran, A. (2020). COVID-19: Impending Situation Threatens to Deepen Nigeria's Education CrisisThelma 7.

- Onyekwena, C., Ekeruche, M.A. (2020). Understanding the impact of the COVID-19 outbreak on the Nigerian economy (www Document). URL https://www.brookings.edu/blog/africa-infocus/2020/04/08/understanding-theimpact-of-thecovid-19-outbreak-on-the-nigerian- economy/ (accessed 6.30.20).

- Ozili, P.K. (2020). Covid-19 Pandemic and Economic Crises: The Nigerian Experience and Structural Cause (April2, 2020. Available at SSRN: http// ssrn.com/abstract=3567419.

- Sanni, K. (2020). Nigerian Businesses Lament Impact of Coronavirus in China (www Document). All Africa.com. URL https://allafrica.com/stories/202003080024.html (accessed 6.30.20).

- Seth, N.J. Impact of Covid-19 (Corona Virus) on Small and Medium Enterprise (SMES) in Pakistan.

Cite This Article: Olusanya Faboyede (2022). Effects of COVID-19 Lockdown on Small Scale Business Owners in Akoko South West Local Government Area of Ondo State, Nigeria. EAS J Humanit Cult Stud, 4(1), 7-14. 